\title{
PENINGKATAN KEMAMPUAN LITERASI SAINS MAHASISWA MELALUI PENERAPAN MODEL PROBLEM SOLVING LABORATORY PADA MATAKULIAH PRAKTIKUM BIOLOGI SISTEM
}

\author{
Halim Simatupang ${ }^{*}$, Aryeni, Dirga Purnama \\ Prodi Pendidikan Biologi, Jurusan Biologi FMIPA, Universitas Negeri Medan \\ Jl. Willem Iskandar Psr V Medan 20221 \\ *E-Mail: halim@unimed.ac.id
}

\begin{abstract}
ABSTRAK
Tujuan penelitian ini adalah 1) Untuk mengembangkan penuntun praktikum dan pedoman penilaian praktikum biologi sistem dengan implementasi model Problem Solving Laboratory untuk meningkatkan kemampuan literasi sains; 2) Mendeskripsikan proses praktikum biologi sistem dengan implementasi model Problem Solving Laboratory untuk meningkatkan kemampuan literasi sains., 3) Mendeskripsikan peningkatan literasi sains mahasiswa. Penelitian menggunakan metode kualitatif, dengan pendekatan Penelitian dan Pengembangan (Research and Development), Model Dick, Carey, \& Carey. Analisis data dalam penelitian ini adalah deskriptif, yaitu menjelaskan suatu permasalahan gejala, atau keadaan sebagaimana adanya data yang diperoleh dalam penelitian ini adalah data kualitatif. Hasil penelitian a) Rerata Ranah sikap dan berpikir ilmiah praktikum biologi sistem berbasis problem solving laboratory pada praktikum pertama dengan judul uji Glukosa dengan fehling A dan B yaitu kelompok 1 sebesar 48,8\%, kelompok 2 sebesar 47,6\%, kelompok 3 sebesar $48,4 \%$, dan kelompok 4 sebesar 35,3\%. Pada praktikum kedua dengan judul uji Yodin pada amilum yaitu yaitu kelompok 1 sebesar 84,2\%, kelompok 2 sebesar 83,7\%, kelompok 3 sebesar 85\%, dan kelompok 4 sebesar $85,1 \%$ dengan rerata peningkatan sekitar $34,8 \%$; b) Rerata ranah keterampilan proses sains praktikum biologi sistem berbasis problem solving laboratory pada praktikum pertama dengan judul uji Glukosa dengan fehling $A$ dan B yaitu kelompok 1 sebesar 65\%, kelompok 2 sebesar $60 \%$, kelompok 3 sebesar 67,5\%, dan kelompok 4 sebesar 70\%. Pada praktikum kedua dengan judul uji Yodin pada amilum yaitu kelompok 1 sebesar 87,5\%, kelompok 2 sebesar 82,5\%, kelompok 3 sebesar 85\%, dan kelompok 4 sebesar 90\% dengan rerata peningkatan sekitar $20,65 \%$. Peningkatan literasi sains yang dipengaruhi oleh penerapan model problem solving laboratory dilihat dilihat dari 2 aspek yaitu 1) peningkatan sikap dan berpikir ilmiah sekitar 34,8\% dan 2) Keterampilan proses sains dengan peningkatan sekitar 20,65\%.
\end{abstract}

Kata Kunci: problem solving laboratory, Literasi Sains

\section{PENDAHULUAN}

Pendidikan sains memiliki peran yang penting dalam menyiapkan manusia memasuki dunia kehidupannya, agar mahasiswa dapat beradaptasi dengan era dunia kerja dan globalisasi, salah satunya adalah seorang mahasiswa harus memiliki kemampuan literasi sains. Dalam penelitiannya (Sandi, 2010) mengungkapkan bahwa literasi sains merupakan suatu hal yang penting untuk dikuasai setiap individu. Literasi sians merupakan salah satu ranah studi Programme For International Studenst Assessmet (PISA). Dalam konteks PISA, Literasi Sains didefenisikan sebagai kemampuan untuk menggunakan pengetahuan sains, mengidentifikasi pertanyaan, dan menarik kesimpulan berdasarkan bukti-bukti, dalam rangka memahami dan membuat keputusan berkenaan dengan alam serta perubahan yang dilakukan terhadap alam melalui aktivitas manusia.
Kemampuan literasi sains adalah kemampuan untuk terlibat dalam masalah sains sehingga menjadi masyarakat yang peka terhadap sains dan teknologi. Sedangkan literasi sains menurut PISA (2015) diartikan sebagai kemampuan untuk terlibat dalam masalah yang berhubungan dengan sains, dan dengan ide-ide ilmu pengetahuan sehingga menjadi masyarakat yang reflektif. Manusia yang dikatakan literate terhadap sains, akan bersedia untuk terlibat dalam hal-hal yang berkaitan dengan ilmu pengetahuan dan teknologi sehingga memerlukan kompetensi untuk menjelaskan fenomena ilmiah, mengevaluasi dan merancang penyelidikan ilmiah serta menginterpretasi data dan bukti ilmiah. Definisi literasi sains ini memandang bukan hanya pemahaman terhadap pengetahuan sains, tetapi lebih bersifat multidimensional. Rahmatunisa (2013) mengungkapkan bahwa pembelajaran 
literasi sains salah satunya dapat dilakukan melalui kegiatan praktikum.

Mahasiswa Fakultas Matematika dan IImu Pengetahuan Alam (FMIPA), Universitas Negeri Medan (Unimed) semester I TA 2017/2018 memperoleh mata kuliah praktikum Biologi Sistem, mata kuliah praktikum Biologi Sistem ini membahas tentang dasar-dasar praktikum biologi sistem, mulai dari penggunaan mikroskop, mengamati sel-sel hewan dan tumbuhan, dll. Mahasiswa yang mengambil matakuliah praktikum biologi sistem adalah mahasiswa baru angkatan 2017 yang belum memiliki latar belakang pengetahuan tentang langkah-langkah ilmiah dan kemampuan literasi sainsnya sangat kurang, serta praktikum selama ini yang dilakukan adalah belum menekankan pentingnya literasi sains terlebih dahulu sebelum melakukan kegiatan ilmiah untuk memperloleh pengetahuan ilmiah, sesuai pendapat Korpan (2009) literasi sains merupakan kemampuan menerapkan pengetahuan ilmiah dan pemahaman sains, dimana kemampuan tersebut mencakup kemampuan mengidentifikasi samalah untuk penyelidikan, merumuskan hipotesis, dan merancang serta melaksanakan penelitian/praktikum.

Sehubungan dengan hal tersebut, perlu dilakukan penelitian untuk memahami bagaimana literasi sains mahasiswa angkatan 2017 yang mengambil matakuliah praktikum biologi umum, praktikum yang dimaksud adalah praktikum yang mengimplementasikan model Problem solving laboratory untuk meningkatkan kemampuan literasi sains mahasiswa biologi yang mengambil matakuliah praktikum biologi sistem.

Menurut Elanawati (2010) model problem solving laboratory adalah model pembelajaran yang memberikan permasalahan dalam kelas, dan teknik penyelesaian permasalahan tersebut dilakukan dengan kegiatan laboratorium kemudian melakukan diskusi dalam kelas untuk menyampaikan konsep yang telah ditemukan. Kegiatan praktikum problem solving laboratory terbagi menjadi tiga tahapan, yang pertama adalah tahapan pre-experiment tahap ini dilaksanakan sebelum berlangsungnya eksperimen, tahap ini mencakup merumuskan tujuan dan prosedur percobaan, merumuskan alat dan bahan, melakukan prediksi, dan menjawab pertanyaan metode yang berbentuk penyusunan laporan awal. Yang kedua adalah tahap experiment dan eksplorasi, yaitu kegiatan yang dilakukan dalam kegiatan percobaaan seperti merakit alat dan mengambil data hasil percobaan. Tahap yang terakhir adalah tahap post-experiment, pada tahap ini mahasiswa mendiskusikan data yang diperoleh dari hasil pengukuran dalam percobaan, analisis percobaan, kesimpulan secara umum, dan juga mendiskusikan hasil percobaan aitannya dengan isu teknologi dan fenomena sains yang terjadi.

Rumusan masalah penelitian ini yaitu: 1 ) Bagaimana penuntun praktikum dan pedoman penilaian praktikum biologi sistem dengan implementasi model Problem solving laboratory untuk meningkatkan kemampuan literasi sains; 2) Bagaimana proses praktikum biologi sistem dengan implementasi model Problem solving laboratory untuk meningkatkan kemampuan literasi sains; 3 ) Bagaimana peningkatan kemampuan literasi sains mahasiswa yang mengikuti praktikum biologi sistem dengan implementasi model Problem solving laboratory.

\section{METODE PENELITIAN}

Penelitian menggunakan metode kualitatif, dengan pendekatan Penelitian dan Pengembangan (Research and Development), Model Dick, Carey, \& Carey (Dick, Carey, \& Carey, 2009). Pengamatan terhadap proses praktikum Biologi sistem dilakukan pada dua proses praktikum biologi selama periode penelitian. Pengumpulan data dilakukan pada satu kali sebelum penerapan model praktikum berbasis problem solving laboratory dan tiga kali sesudah penerapan model praktikum berbasis peoblem solving laboratory. Instrumen yang digunakan dalam penelitian ini terdiri atas (1) pedoman validasi prosedur praktikum berbasis model praktikum berbasis problem solving laboratory; (2) Pedoman observasi di laboratorium.

Analisis data dalam penelitian ini adalah deskriptif, yaitu menjelaskan suatu permasalahan gejala, atau keadaan sebagaimana adanya dan bukan menguji hipotesa. Data yang diperoleh dalam penelitian ini adalah data kualitatif. 


\section{HASIL PENELITIAN}

\section{Validator Terhadap Prosedur Praktikum}

Penelitian ini dilaksanakan 2 kali pertemuan, pertemuan pertama senin tanggal 9 oktober 2017 dan senin 16 oktober 2017, bertempat di laboratorium biologi Unimed, sebelum melaksanakan praktikum biologi sistem berbasis problem solving laboratory. Terlebih dahulu prosedur kerja praktikum divaliditas oleh 2 orang ahli yaitu: Dra. Masdiana Sinambela, M.Si selaku penilai konten dengan jabatan ketua KDBK Biologi sistem, dan Ahli pendidikan yaitu Dr. Widya Astuti, M.Pd. Berdasarkan Penilaian dua ahli mengenai prosedur kerja praktikum biologi sistem yang disusun, dengan aspek yang dinilai yaitu 1 ) Kebenaran konsep, 2) Kejelasan kalimat dan keterbacaan, 3) tingkat keterlaksanaan praktikum, 4) integrasi model problem solving laboratory, dan 5) Evaluasi praktikum secara lengkap dapat dilihat pada tabel dibawah ini.

Tabel 1. Presentase Penilaian validator terhadap prosedur kerja praktikum Biologi sistem berbasis problem solving laboratory

\begin{tabular}{lcccc}
\hline \multicolumn{1}{c}{ Aspek Yang Dinilai } & $\begin{array}{c}\text { Skor } \\
\text { Validator 1 }\end{array}$ & $\begin{array}{c}\text { Skor } \\
\text { Validator 2 }\end{array}$ & Rerata & Kategori \\
\hline $\begin{array}{l}\text { Kebenaran konsep } \\
\text { Kejelasan kalimat dan } \\
\text { keterbacaan }\end{array}$ & 10 & 9 & 79,2 & $\begin{array}{c}\text { Sesuai } \\
\text { Tingkat keterlaksanaan } \\
\text { praktikum }\end{array}$ \\
$\begin{array}{l}\text { Integrasi model problem solving } \\
\text { laboratory }\end{array}$ & 11 & 11 & 91,7 & Sangat Sesuai \\
\begin{tabular}{l} 
Evaluasi praktikum \\
\hline
\end{tabular} & 19 & 11 & 91,7 & Sangat Sesuai \\
\hline
\end{tabular}

Dari tabel 1 dapat dilihat bahwa presentase penilaian validator terhadap prosedur kerja praktikum biologi sistem berbasis problem solving laboratory dari 5 aspek yang diamati yaitu 1) kebenaran konsep memperoleh rerata 79,2 dengan kategori sesuai, 2) kejelasan kalimat dan keterbacan 91,7 kategori sangat sesuai; 3) tingkat keterlaksanaan 91,7 kategori sangat sesuai; 4) Integrasi model problem solving laboratory 92,5 kategori sangat sesuai; 5) Evaluasi praktikum 81,25 kategori sesuai.

\section{Penilaian Sikap dan Berpikir Ilmiah}

Data ranah sikap dan berpikir ilmiah mahasiswa pada praktikum pertama yaitu uji Glukosa dengan fehling A dan B dan praktikum kedua uji Yodin pada amilum, ranah sikap dan berpikir ilmiah diisi oleh 4 observer yang setiap observer mengamati 1 kelompok praktikum mahasiswa selama praktikum berlangsung, analisis data dilakukan dengan cara membagi skor yang didapat dengan skor maksimal kemudian dikalikan dengan $100 \%$. Presentase yang diperoleh tiap aspek setiap kelompok praktikum dapat dilihat pada tabel dibawah ini. 
Tabel 2. Observasi Sikap dan Berpikir Ilmiah Praktikum Biologi Sistem Berbasis problem solving laboratory (\%)

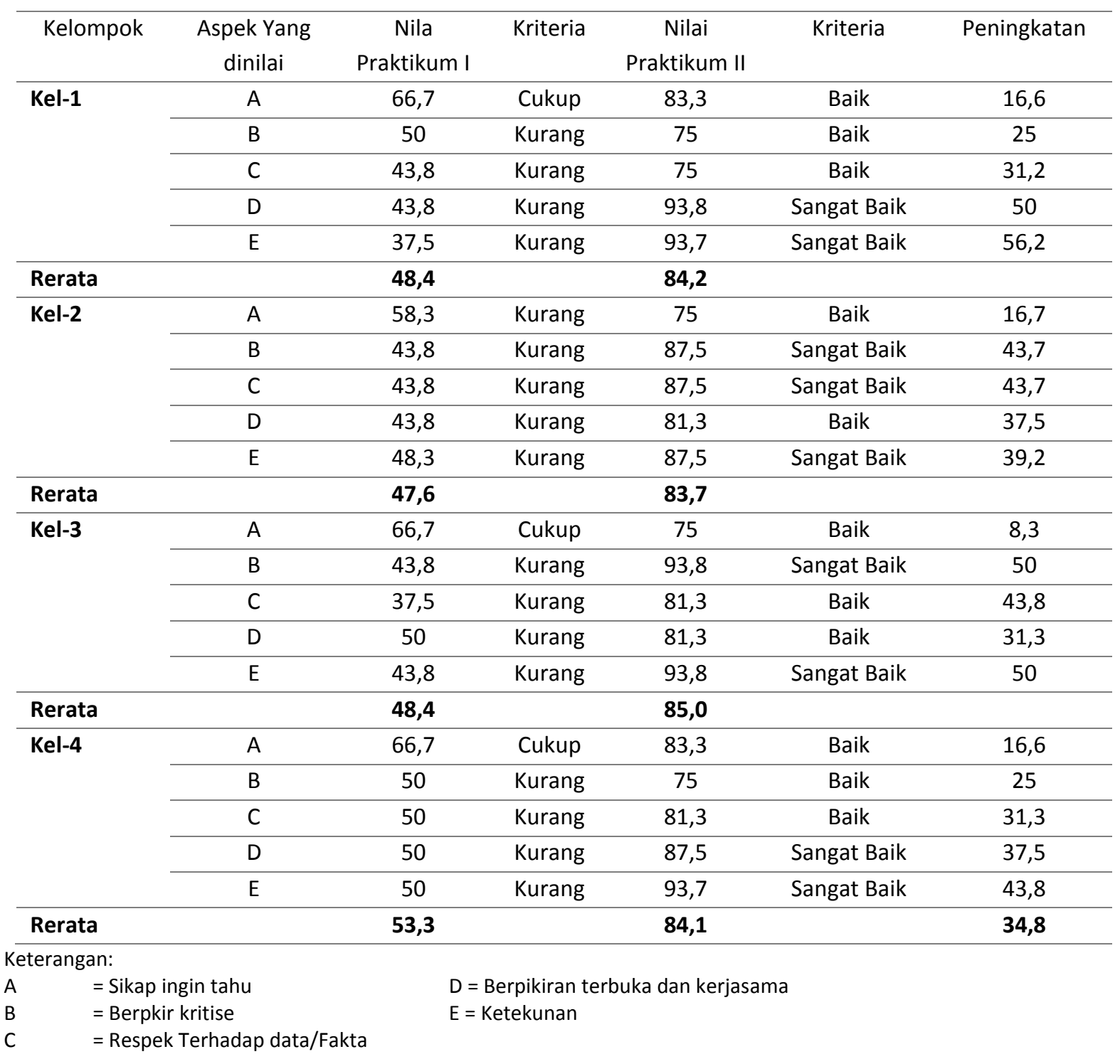

Dari Tabel 2 diatas diperoleh rerata Ranah sikap dan berpikir ilmiah praktikum biologi sistem berbasis problem solving laboratory pada praktikum pertama dengan judul uji Glukosa dengan fehling A dan B yaitu kelompok 1 sebesar 48,8\%, kelompok 2 sebesar 47,6\%, kelompok 3 sebesar 48,4\%, dan kelompok 4 sebesar 35,3\%. Pada praktikum kedua dengan judul uji Yodin pada amilum yaitu yaitu kelompok 1 sebesar $84,2 \%$, kelompok 2 sebesar 83,7\%, kelompok 3 sebesar $85 \%$, dan kelompok 4 sebesar $85,1 \%$ dengan rerata peningkatan sekitar $34,8 \%$.

\section{Penilaian Keterampilan Proses}

Data ranah keterampilan proses sains praktikum biologi sistem mahasiswa pada praktikum yaitu uji Glukosa dengan fehling A dan B dan praktikum kedua uji Yodin pada amilum, ranah sikap dan berpikir ilmiah diisi oleh 4 observer yang setiap observer mengamati 1 kelompok praktikum mahasiswa selama praktikum berlangsung, analisis data dilakukan dengan cara membagi skor yang didapat dengan skor maksimal kemudian dikalikan dengan $100 \%$. Presentase yang diperoleh tiap aspek setiap kelompok praktikum dapat dilihat pada tabel dibawah ini. 
Tabel 3 Hasi Observasi Keterampilan Proses Sains Praktikum Biologi Sistem Berbasis problem solving laboratory

\begin{tabular}{|c|c|c|c|c|c|c|c|c|c|}
\hline \multirow{2}{*}{$\begin{array}{l}\text { Komponen } \\
\text { Pengamatan }\end{array}$} & \multicolumn{4}{|c|}{ Nilai Praktikum I } & \multicolumn{4}{|c|}{ Nilai Praktikum II } & \multirow[t]{2}{*}{ Peningkatan } \\
\hline & K-1 & $\mathrm{K}-2$ & K-3 & K-4 & K-1 & $\mathrm{K}-2$ & K-3 & $\mathrm{K}-4$ & \\
\hline 1 & 3 & 3 & 3 & 3 & 3 & 3 & 3 & 3 & \\
\hline 2 & 3 & 2 & 3 & 3 & 4 & 3 & 4 & 4 & \\
\hline 3 & 3 & 2 & 3 & 3 & 3 & 4 & 4 & 3 & \\
\hline 4 & 3 & 2 & 3 & 3 & 3 & 2 & 3 & 4 & \\
\hline 5 & 3 & 4 & 2 & 3 & 3 & 4 & 3 & 4 & \\
\hline 6 & 2 & 2 & 3 & 3 & 4 & 4 & 4 & 4 & \\
\hline 7 & 2 & 2 & 2 & 4 & 4 & 4 & 3 & 4 & \\
\hline 8 & 2 & 2 & 3 & 2 & 3 & 3 & 4 & 4 & \\
\hline 9 & 3 & 3 & 3 & 2 & 4 & 3 & 3 & 3 & \\
\hline 10 & 2 & 2 & 2 & 2 & 4 & 3 & 3 & 3 & \\
\hline Presentase & 65 & 60 & 67,5 & 70 & 87,5 & 82,5 & 85 & 90 & \\
\hline Rerata & \multicolumn{4}{|c|}{65,6} & \multicolumn{4}{|c|}{86,25} & 20,65 \\
\hline Kriteria & $\begin{array}{c}\text { Cuku } \\
\text { p }\end{array}$ & Kurang & $\begin{array}{c}\text { Cuku } \\
p\end{array}$ & $\begin{array}{c}\text { Cuku } \\
p\end{array}$ & $\begin{array}{l}\text { Sanga } \\
\text { t Baik }\end{array}$ & Baik & Baik & $\begin{array}{l}\text { Sanga } \\
\text { t Baik }\end{array}$ & \\
\hline
\end{tabular}

Keterangan;

1. Melakukan identifikasi terhadap alat dan bahan serta data hasil percobaan yang diamati

2. Menggunakan semua indera dengan melihat, merasakan, mendengar, meraba dan mencium untuk mendapatkan data sesuai dengan percobaan yang dilakukan

3. Menggolongkan alat, bahan dan materi pelajaran dalam percobaan secara jelas dan tepat

4. Menjawab dan mengajukan pertanyaan serta memberikan solusi atau pendapat dalam menjawab pertanyaan di dalam diskusi kelompok

5. Mencatat dan merangkum hasil percobaan serta menuliskan jawaban pertanyaan dalam penuntun praktikum sesuai dengan hasil diskusi kelompok tersebut kedalam lembar

6. Menyampaikan hasil diskusi secara jelas, tepat, dan efektif

7. Membuat perkiraan atau dugaan sementara sebelum melakukan percobaan

8. Menyesuaikan prediksi yang telah dibuat dengan teori dan materi yang diajarkan

9. Membuat suatu pembuktian untuk menguji prediksi yang telah dibuat dengan melakukan percobaan sesuai dengan penuntun praktikum yang didapatkan

10. Mengkaitkan data yang diperoleh dari hasil percobaan dengan teori yang ada

Dari Tabel 3 diatas diperoleh rerata ranah keterampilan proses sains praktikum biologi sistem berbasis problem solving laboratory pada praktikum pertama dengan judul uji Glukosa dengan fehling A dan B yaitu kelompok 1 sebesar $65 \%$, kelompok 2 sebesar 60\%, kelompok 3 sebesar 67,5\%, dan kelompok 4 sebesar 70\%. Pada praktikum kedua dengan judul uji Yodin pada amilum yaitu kelompok 1 sebesar $87,5 \%$, kelompok 2 sebesar 82,5\%, kelompok 3 sebesar $85 \%$, dan kelompok 4 sebesar $90 \%$ dengan rerata peningkatan sekitar $20,65 \%$.

\section{PEMBAHASAN}

\section{Penilaian Sikap dan Berpikir IImiah}

Ranah sikap dan berpikir ilmiah praktikum biologi sistem berbasis problem solving laboratory pada praktikum pertama dengan judul uji Glukosa dengan fehling A dan B yaitu kelompok 1 sebesar 48,8\%, kelompok 2 sebesar 47,6\%, kelompok 3 sebesar 48,4\%, dan kelompok 4 sebesar 35,3\%. Pada praktikum pertama ini beberapa catatan temuan observer adalah 1) praktikan dalam melakukan praktikum banyak yang tidak melakkan percobaan dengan sistematik 
sesuai dengan prosedur yang telah ada, 2) pembagian kerja antar anggota kelompok tidak maksimal, terlihat ada anggota kelompok yang tidak maksimal mengikuti praktikum, praktikan enggan mengulang prosedur kerja yang tidak sistematis. Temuan ini diperoleh dikarenakan mahasiswa sebagai praktikan belum terbiasa dengan langkah pendekatan problem solving laboratory sesuai dengan pendapat Mudjiono (2010) bahwa belajar memerlukan adanya pembiasaan dan latihan. Kendala-kendala yang diperoleh pada praktikum pertama akan dilakukan perbaikan pada pertemuan kedua.

Temuan kelemahan pada praktikum pertama menjadi bahan refleksi buat dosen dan para asisten serta observer untuk pertemuan kedua lebih menekankan hal-hal yang perlu diperbaiki pada pertemuan pertama. Pada praktikum kedua dengan judul uji Yodin pada amilum yaitu yaitu kelompok 1 sebesar 84,2\%, kelompok 2 sebesar 83,7\%, kelompok 3 sebesar $85 \%$, dan kelompok 4 sebesar $85,1 \%$ dengan rerata peningkatan sekitar $34,8 \%$. Pada praktikum kedua terjadi peningtakan dari 5 aspek yang diamati, peroleh tertinggi diperoleh pada aspek ketekunan dimana ketiaka praktikan tekun dalam mengerjakan prosedur kerja yang diharapkan maka proses perbaikan akan tercapai. Sanjaya (2006) menyatakan bahwa peroses pengumpulan data bukan hanya memerlukan motivasi yang kuat tetapi juga membutuhkan ketekunan dan kemampuan mengunakan potensi berpikir peserta didik.

\section{Penilaian Keterampilan Proses}

Keterampilan proses sains menurut Rusman (2005) adalah suatu keterampilan yang melibatkan keterampilan dimensi pengetahuan, manual, dan sosial. Keterampilan yang proses sains yang diukur dalam penelitian ini meliputi 10 aspek. Ranah keterampilan proses sains praktikum biologi sistem berbasis problem solving laboratory pada praktikum pertama dengan judul uji Glukosa dengan fehling A dan B yaitu kelompok 1 sebesar $65 \%$, kelompok 2 sebesar $60 \%$, kelompok 3 sebesar $67,5 \%$, dan kelompok 4 sebesar $70 \%$. Adapun kelemahan daalm praktikum pertama ditemukan 1) ada beberapa kelompok praktikan yang tidak membuat dugaan semestara sebelum melakukan percobaan padahal menurut Soekarjo (1993) merumuskan hipotesis merupakan bagian dai langkah-langkahmetode imiha yang memiliki kegunaan untuk memberikan arah kepada penelitian, jika hipotesis tidak ada maka arah penelitian tidak akan tercapai 2) Menyesuaikan prediksi yang telah dibuat dengan teori dan materi yang diajarkan, 3) Mengkaitkan data yang diperoleh dari hasil percobaan dengan teori yang ada.

Pada praktikum kedua dengan judul uji Yodin pada amilum yaitu kelompok 1 sebesar $87,5 \%$, kelompok 2 sebesar 82,5\%, kelompok 3 sebesar $85 \%$, dan kelompok 4 sebesar $90 \%$ dengan rerata peningkatan sekitar 20,65\%. Dari data diatas dapat disimpulkan bahwa penerapan model pembelajaran problem solving laboratory dapat meningkatkan keterampilan proses sains sebanyak 20,65\% sesuai dengan pendapat Ellianawati, (2010) bahwa model problem solving laboratory adalah suatu model pembelajaran yang yang berorientasi pada keterlibatan mahasiswa dalam proses belajarnya, dimana mahasiswa mengagali permasalahan /kritis terdap permasalahan sehingga mahasiswa berusaha mencari pemecahannya sendiri. Hal ini dimaksudkan utnuk memberikan keluasan pada siswa untuk aktif berpikir dan melatih berpikir dan melatih keterampilan dalam merencanakan dan menyelesaikan masalah yang dihadapinya, sehingga pengembangan, keterampilan, dan sikap ilmiah mahasiswa dapat lebih optimal.

Peningkatan literasi sains yang dipengaruhi oleh penerapan model problem solving laboratory dilihat dilihat dari 2 aspek yaitu 1) peningkatan sikap dan berpikir ilmiah sekitar $34,8 \%$ dan 2) Keterampilan proses sains dengan peningkatan sekitar $20,65 \%$.

\section{SIMPULAN}

Rerata Ranah sikap dan berpikir ilmiah praktikum biologi sistem berbasis problem solving laboratory pada praktikum pertama dengan judul uji Glukosa dengan fehling A dan B yaitu kelompok 1 sebesar 48,8\%, kelompok 2 sebesar 47,6\%, kelompok 3 sebesar 48,4\%, dan kelompok 4 sebesar $35,3 \%$. Pada praktikum kedua dengan 
judul uji Yodin pada amilum yaitu yaitu kelompok 1 sebesar 84,2\%, kelompok 2 sebesar 83,7\%, kelompok 3 sebesar $85 \%$, dan kelompok 4 sebesar $85,1 \%$ dengan rerata peningkatan sekitar $34,8 \%$. Rerata ranah keterampilan proses sains praktikum biologi sistem berbasis problem solving laboratory pada praktikum pertama dengan judul uji Glukosa dengan fehling A dan B yaitu kelompok 1 sebesar $65 \%$, kelompok 2 sebesar $60 \%$, kelompok 3 sebesar $67,5 \%$, dan kelompok 4 sebesar $70 \%$. Pada praktikum kedua dengan judul uji Yodin pada amilum yaitu kelompok 1 sebesar 87,5\%, kelompok 2 sebesar 82,5\%, kelompok 3 sebesar $85 \%$, dan kelompok 4 sebesar $90 \%$ dengan rerata peningkatan sekitar $20,65 \%$.

\section{DAFTAR PUSTAKA}

Anggraini. 2013. Pengelolaan laboratorium Biologi Untuk Menunjang Kinerja Penggunaan Dan Pengelolaan Laboratorium Biologi SMA Negeri 2 Wonogiri. Jurnal Biologi. Semarang. Universitas Negeri Semarang.

Champagne, A.B. (2009). A critical evaluation of PISA's assessment of science literacy. June 2, 2009. Diambil 9 Februari 2017. dari https://edsurveys.rti.org/PISA/documents/C hampagne Final.pdf

Elanawati,2012 "Model Kegiatan Laboratorium Berbasis Problem Solving pada Pembelajaran Gelombang dan Optik untuk Meningkatkan Keterampilan Proses Sains Mahasiswa", Jurnal Exacta (2), 3 (2012)

Korpan, C. A., Bisanz, G.L., Bisanz,J., \& Henderson, J. (1997). Assessing literacy in science: Evaluation of scientific news briefs. Science Education, 81, 515-532

Liu, X. (2009). Beyond science literacy: science and the public. Editors: Richard K. Coll \& Neil Taylor. International Journal of Environmental \& Science Education, Special Issue on Scientific Literacy, 4, (3), July 2009, 301-311
OECD (2009). PISA 2009 Assessment Framework: Key Competencies in reading, mathematics and science, Paris: OECD.

Rahmatunnisa Djuniar, Ernawati, I. Lestari, 2013. "Pembelajaran Berbasis Literasi Sains Pada Materi Larutan Elektrolit dan Non Elektrolit di SMAN I Pontianak", Jurnal pendidikan kimia FKIP Untan. 2 (2013).

Sandi, M.Irsyan, A. Setiawan, dan Heni Rusnayanti, 2010. "Analisiss Buku Ajar Fisika SMA Kelas X di Kota Bandung Berdasarkan komponen Literasi Sains". Jurnal Pendidikan Fisika Universitas Pendidikan Indonesia

Sagala, S. 2006. Konsep Dan Makna Pembelajaran. Bandung. Alfabeta

Subiantoro. 2010. Pentingnya Praktikum dalam Pembelajaran IPA (makalah) Yogyajarta, Universitas Negeri Yogyakarta.

Suparno. 2007. Metodologi Pembelajaran Fisika. Yogyajarta, Universitas Negeri Yogyakarta.

Schmidt, W., Leroi, G., Billinge, S., Lederman, L., Champagne, A., Hake, R., Heron, P., McDermott, L., Myers, F., Otto, R., Pasachoff, J., Pennypacker, C., \& Williams, P. (2011). Towards coherence in science instruction: A framework for science literacy. Research Report Vol. 8, October 2011, Michigan State University.

Sudirman A.M. 1992. Interaksi dan Motivasi Belajar mengajar. Jakarta. Rajawali

Tresma Sastrawijaya.1998. Proses Belajar Mengajar Kimia. Jakarta: Depdikbud

Winaputra. 1994. Belajar Dan Pembelajaran. Jakarta. Unversitas Terbuka 